\title{
The Influence of Brand Equity to Purchasing Decisions on Wardah Products (studies conducted at Wardah Beauty House stores, Surabaya)
}

\author{
Vebri Aria Rahma \\ Narotama University, Surabaya \\ vebriariarahma@gmail.com
}

\begin{abstract}
This study aims to analyze the influence of brand equity which includes: brand awareness, brand association, perceived quality, and brand loyalty on purchasing decisions at Wardah Beauty House Surabaya stores. The authors used a survey, where the authors distributed questionnaires totaling 100 questionnaires to consumers or customers in Wardah Beauty House Surabaya stores. This is a quantitative research. Analyzed using multiple linear regression analisys and using SPSS 18.0. Based on the results of the study showed that brand equity variables consisting of brand awareness, brand association, perceived quality, and brand loyalty simultaneously have a significant effect on purchasing decisions. Brand awareness doesn't have a partially significance influence on purchasing decisions.
\end{abstract}

Keywords: Brand Equity, Brand Awareness, Brand Associations, Perceived Quality, Brand Loyalty, and Purchasing Decisions

\section{INTRODUCTION}

It's no secret for women to do beauty treatments, especially facial care. And cosmetics is one tool to realize the need for beauty. Cosmetics or beauty tools today are very diverse and varied, there are hundreds or even thousands of types of brands and their respective uses. But consumers will see the brand as the most important part of a product and that will be one of the added values in a product.

One of them is the modern lifestyle today is a hijab woman. The existence of this hijab trend is in line with the development of halal cosmetics which are increasingly prevalent in the cosmetics market. One type of cosmetics that has the line "halal cosmetics" is Wardah cosmetic products with a model that is displayed using modern hijab clothes. The many cosmetics offered on the market make competition in the future more competitive because consumers have many choices of products, ranging from domestic brands to international brands available in various brands and satisfying quality. This requires marketers not only pay attention to the product from the physical side and its benefits, but also what and how a consumer gets and manages information so that information is generated for consideration. Here are ten of the most popular female cosmetic products in Indonesia during 2018:

Table 1. The Most Popular Cosmetic Brands in Indonesia

The Influence of Brand Equity to Purchasing Decisions on Wardah Products (studies conducted at Wardah Beauty House stores, Surabaya)

Vebri Aria Rahma 


\begin{tabular}{|c|c|c|}
\hline No & Brand & Percentage \\
\hline 1. & Wardah & $37,8 \%$ \\
\hline 2. & Pixy & $10,1 \%$ \\
\hline 3. & Sari Ayu & $8,7 \%$ \\
\hline 4. & Viva & $6,6 \%$ \\
\hline 5. & Ponds & $6,6 \%$ \\
\hline 6. & Latulipe & $3,9 \%$ \\
\hline 7. & Oriflame & $3,6 \%$ \\
\hline 8. & Maybelline & $3,3 \%$ \\
\hline 9. & Revlon & $2,9 \%$ \\
\hline 10. & Mustika Ratu & $1,9 \%$ \\
\hline
\end{tabular}

Along with the increasingly rapid competition in the world of commerce, it is not surprising if the brand is the most important part in improving the quality of a product created by a company.

Based on the description of the background that has been explained, the authors are interested in conducting research with the title "The Influence of Brand Equity to Purchasing Decisions on Wardah Products (studies conducted at Wardah Beauty House stores, Surabaya)“6

Based on the background that has been described, the problems that can be raised by the author in this study are as follows:

1. Does the brand awareness have a significant effect partially on the purchase decisions of Wardah products at Wardah Beauty House Surabaya?

2. Does the brand association have a significant effect partially on the purchase decisions of Wardah products at Wardah Beauty House Surabaya?

3. Does the perceived quality have a significant effect partially on the purchase decisions of Wardah products at Wardah Beauty House Surabaya?

4. Does the brand loyalty have a significant effect partially on the purchase decisions of Wardah products at Wardah Beauty House Surabaya?

5. Does the brand equity variable consisting of brand awareness, brand association, perceived quality, and brand loyalty, have a simultaneous significant effect on the purchase decisions of Wardah products at Wardah Beauty House Surabaya?

The objectives of this study are:

1. To analyze the influence and significance of brand awareness on purchasing decisions of Wardah products at Wardah Beauty House Surabaya.

2. To analyze the influence and significance of brand association on purchasing decisions of Wardah products at Wardah Beauty House Surabaya.

3. To analyze the influence and significance of perceived quality on purchasing decisions of Wardah products at Wardah Beauty House Surabaya.

4. To analyze the influence and significance of brand loyalty on purchasing decisions of Wardah products at Wardah Beauty House Surabaya.

5. To analyze the significant effect simultaneously brand equity variables consisting of brand awareness, brand association, perceived quality, and brand loyalty, towards the decision to purchase Wardah products at Wardah Beauty House Surabaya.

The Influence of Brand Equity to Purchasing Decisions on Wardah Products (studies conducted at Wardah Beauty House stores, Surabaya) 


\section{BASIC THEORY}

\subsection{Brand Equity}

Brand equity is the value of a brand based on how strong the brand value has brand loyalty value, consumer awareness of the brand, perceived quality, brand association, and various other assets such as patents, trademarks and relationships distribution network (Amstrong, 2003).

And it can also be interpreted that brand equity is all wealth in a good brand name, symbol, which as a whole has a multidimensional concept, which consists of brand awareness, perceived quality, brand association, brand loyalty, for the added value of a product so as to increase profit company in the future.

\subsection{Brand Awareness}

Brand awareness is the ability of consumers to recognize or recall that a brand is part of a particular product category (Aaker, 1991).

The role of brand awareness in brand equity depends on the degree of awareness achieved by a brand (Kartono, 2007a). There are 4 indicators that can be used to find out how far consumers are aware of a brand, including:
1. Recall
2. Recognition
3. Purchase
4. Consumption

\subsection{Brand Association}

Brand association is "all things related to memory about the brand" (Freddy Rangkuti, 2002).

In measuring the functions and benefits of brand associations (brand association) can be done through six main dimensions in the book Marketing Scales (Tjiptono, Fandy, 2004), that is :

1. Guarantee

2. Personal identification

3. Social Identification

4. Status

5. Willingness to Accept Brand Extensions

\subsection{Perceived Quality}

The perception of quality is the customer's assessment of the overall quality or superiority of a product (Tjiptono, 2005).

Quality perception reflects the customer's overall feeling about a brand. Referring to the opinion of (Darmadi Durianto, 2001), the dimension of quality perception is divided into seven, that is :
1. Performance
2. Services
3. Resilience
4. Reliability

The Influence of Brand Equity to Purchasing Decisions on Wardah Products (studies conducted at Wardah Beauty House stores, Surabaya) 
5. Product Characteristics

6. Compliance with specifications

7. Results

\subsection{Brand Loyalty}

Brand loyalty is a measure of the relationship of a customer to a brand (Kartono, 2007b).

The level of brand loyalty (Durianto, Darmadi, Sugiarto, 2004), is as follows:

1. Switcher

2. Habitual Buyer

3. Statisfied Buyer

4. Likes the Brand

5. Committed Buyer

\subsection{Buying decision}

Purchasing decisions are the stage of the buyer's decision process that is when the consumer actually buys the product. Where consumers recognize the problem, find information about a particular product or brand and evaluate how well each alternative can solve the problem which then leads to a purchasing decision (Kotler dan Amstrong, 2008).

In making a purchasing decision a process is needed. Where in the process is an indicator of specific purchasing decisions, the process of consumer purchasing decisions consists of five stages carried out by a consumer before arriving at a purchase decision and then post-purchase (Kotler, 2016). This shows that the indicator of the buying process carried out by consumers has consequences after the purchase is made.

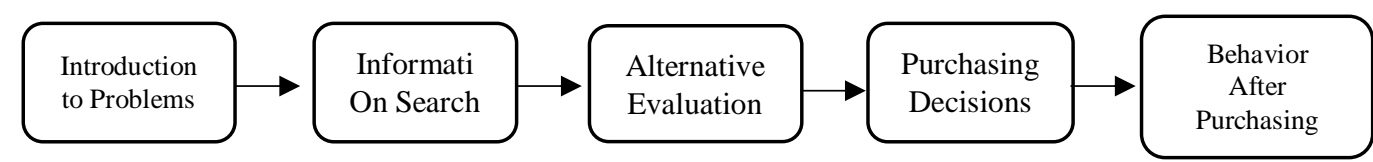

Fig 1. Purchasing Decision Process

The five-stage model of purchasing decisions (Kotler, 2016), that is :

1. Introduction to Problems / Needs

2. Information Search

3. Alternative Evaluation

4. Purchasing Decisions

5. Behavior After Purchasing

The main factors that influence purchasing behavior (Abdullah, 2013), are as follows:

1. Cultural Factors

2. Social Factors

3. Personal Factors

4. Psychological factors

The Influence of Brand Equity to Purchasing Decisions on Wardah Products (studies conducted at Wardah Beauty House stores, Surabaya) 


\section{RESEARCH METHOD}

\subsection{Research Structure}

Based on the review of theory, formulation, and objectives described earlier, the effect of brand awareness, brand association, perceived quality and brand loyalty on purchasing decisions will be shown in Figure 2:

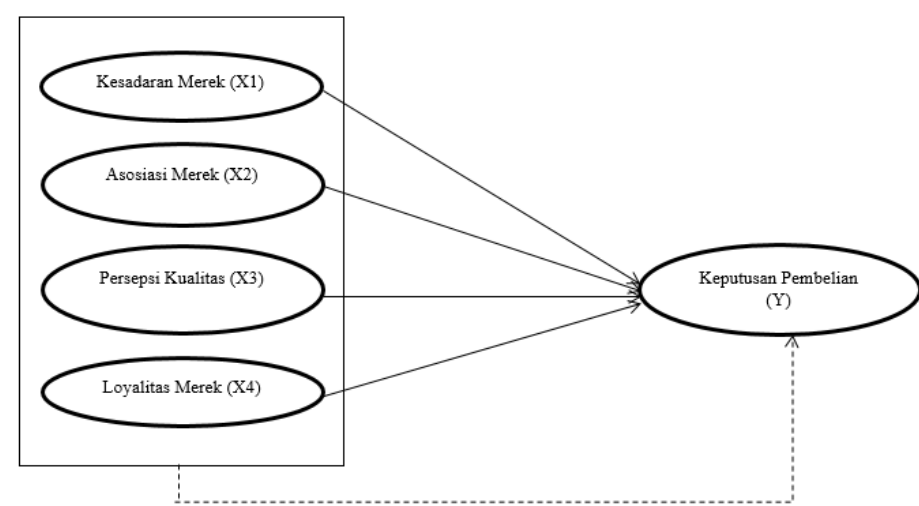

Fig. 1. Research Framework

\subsection{Research Hypotheses}

H1 : Brand awareness (X1) has a partially significant effect on the purchase decision of Wardah products (Y) at Wardah Beauty House Surabaya stores.

$\mathrm{H} 2$ : Brand association (X2) has a partially significant effect on the purchase decision of Wardah products (Y) at Wardah Beauty House Surabaya stores.

H3 : Perceived quality (X3) has a partially significant effect on the purchase decision of Wardah products (Y) at Wardah Beauty House Surabaya stores.

$\mathrm{H} 4$ : Brand loyalty (X4) has a partially significant effect on the purchase decision of Wardah products (Y) at Wardah Beauty House Surabaya stores.

H5 : Brand Awareness (X1), Brand Association (X2), Perceived Quality (X3), and Brand Loyalty (X4) simultaneously have a significant effect on Wardah product purchasing decisions (Y) at Wardah Beauty House Surabaya stores.

\subsection{Technique}

We have used Quantitative technique in this research, which is focused on the collection of numerical data for statistical analysis.

\subsection{Population}

The population in this study is consumers or customers from Wardah Beauty House Surabaya stores. Data collection was based on questionnaire.

\subsection{Sampling Technique}

Sampling is done by simple random sampling technique or method. Samples from this study were taken from the consumer population who purchased products at Wardah Beauty House Surabaya stores.

The Influence of Brand Equity to Purchasing Decisions on Wardah Products (studies conducted at Wardah Beauty House stores, Surabaya)

\section{Vebri Aria Rahma}




\section{RESULTS AND DISCUSSION}

\subsection{Validity Test and Reliability Test}

The test results show that all items in question regarding brand awareness, brand association, quality perception, brand loyalty and purchase decisions are 23 items declared valid because they have a $\mathrm{r}_{\text {count }}$ value $>r_{\text {table. }}$. As a result the reliability test results show Cronbach alpha values of 0.983 and greater than 0.6 . So this research data can be declared reliable.

\subsection{Multiple Regression Analisys}

Multiple linear regression analysis is used to explain how the influence of the independent variables namely Brand Awareness (X1), Brand Association (X2), Perceived Quality (X3), and Brand Loyalty (X4) on the dependent variable is the Purchase Decision (Y). In calculating multiple linear regression analysis, researchers used SPSS 18.0. Summary of data processing can be seen in the following table:

Table. 2. The results of multiple linear regression analysis

\begin{tabular}{lccc}
\hline \multicolumn{1}{c}{ Variable } & $\begin{array}{c}\text { regression } \\
\text { coefficient }\end{array}$ & t & Sig \\
\hline Brand Awareness (X1) & 0,091 & 0,862 & 0,391 \\
Brand Association (X2) & 0,617 & 7,154 & 0,000 \\
Perceived Quality (X3) & $-0,186$ & $-2,042$ & 0,044 \\
Brand Loyalty (X4) & 0,331 & 3,559 & 0,001 \\
\hline
\end{tabular}

$$
\begin{aligned}
& \text { Konstanta }=0,472 \\
& \mathrm{R}=0,792 \\
& \text { Adj } \mathrm{R} \text { Square }=0,612 \\
& \mathrm{~F}=39,992 \\
& \mathrm{Fsig}=0,000 \\
& \mathrm{n}=100 \\
& \text { SEE }=0,384
\end{aligned}
$$

Regression equation models that can be written based on the multiple regression analysis table above are:

$$
\begin{array}{ll}
\mathrm{Y} & =0,472+0,091 \mathrm{X} 1+0,617 \mathrm{X} 2-0,186 \mathrm{X} 3+0,331 \mathrm{X} 4+e_{1} \\
\mathrm{Ymax} & =0,472+0,091 \mathrm{X} 1+0,617 \mathrm{X} 2+(-0,186) \mathrm{X} 3+0,331 \mathrm{X} 4+0,762 \\
\mathrm{Ymin} & =0,472+0,091 \mathrm{X} 1+0,617 \mathrm{X} 2+(-0,186) \mathrm{X} 3+0,331 \mathrm{X} 4-0,762
\end{array}
$$

Based on the equation model above, obtained a constant value of 0.47 , this indicates that the purchase decision $(\mathrm{Y})$ is worth 0.47 units if it is assumed that brand awareness (X1), brand association (X2), perceived quality (X3) and loyalty brand (X4) is 0 . If the value of the independent variable 0 then the dependent variable will be worth 0.47 .

The brand awareness (X1) regression coefficient is 0.091, which means that if Wardah products increase the influence of brand awareness and other brand association variables (X2), perceived quality (X3) and brand loyalty (X4) remain, it will increase the purchasing decision (Y) by 0.091 units. Brand

The Influence of Brand Equity to Purchasing Decisions on Wardah Products (studies conducted at Wardah Beauty House stores, Surabaya) 
association regression coefficient (X2) of 0.617. It means that if Wardah products increase the influence of brand associations and other variables brand awareness (X1), perceived quality (X3) and brand loyalty (X4) remain, it will increase the purchasing decision (Y) by 0.617 units. The regression coefficient of quality perception (X3) is $-0,186$. This means that if Wardah products increase the influence of perceived quality and other variables of brand awareness (X1), brand association (X2) and brand loyalty (X4), then it will increase the purchasing decision (Y) by $-0,186$ units. Brand loyalty (X4) regression coefficient of 0.331 . This means that if Wardah products increase the influence of brand loyalty and other variables of brand awareness (X1), brand associations (X2) and perceptions of quality (X3) remain, it will increase the purchasing decision (Y) by 0.331 units.

Based on the above table data it is known that the $\mathrm{F}_{\text {counts }}$ value obtained is 39.992. This value is greater than $\mathrm{F}_{\text {table }} 2.31$. Also obtained a significance value of $0,000<0,05$. Then Ha is accepted, meaning that the brand awareness variable (X1), brand association (X2), perceived quality (X3) and brand loyalty (X4) simultaneously have a significant effect on Wardah product purchasing decisions (Y)

Based on the table data above, it is known that the value of $t_{\text {counts }}$ brand awareness variable (X1) is $0.862<1.985$. Also obtained a significance value of $0.391>0.05$. This shows that the brand awareness variable (X1) has an effect not partially significant on the purchasing decision variable (Y). The value of the $t_{\text {counts }}$ variable brand association (X2) is $7.154>1.985$. Also obtained a significance value of $0,000<$ 0,05 . This shows that the brand association variable (X2) has a partially significant effect on the purchasing decision variable $(\mathrm{Y})$. The value of $\mathrm{t}_{\text {counts }}$ variable perception of quality (X3) is $-2.042<1,985$. Also obtained a significance value of $0.044<0.05$. This shows that the perceived quality variable (X3) partially has a significant effect on the purchasing decision variable $(\mathrm{Y})$. The value of $\mathrm{t}_{\text {counts }}$ variable brand loyalty (X4) is 3,559 >1,985. Also obtained a significance value of $0,001<0.05$. This shows that the brand loyalty variable (X4) has a partially significant effect on the purchasing decision variable (Y).

Obtained an $\mathrm{R}$ value of 0.792 . The meaning is a correlation or relationship between purchasing decision with 4 independent variables (brand awareness, brand association, perception quality, and brand loyalty) has a strong relationship because the value of $\mathrm{R}$ is $0.792>0.5$. Obtained the coefficient of determination or Adjusted $\mathrm{R}$ square of 0.612 which means that the dependent variable of purchasing decision $(\mathrm{Y})$ can be explained by the independent variable brand awareness (X1), brand association (X2), perceived quality (X3) and brand loyalty (X4) of 0.612 or $61.2 \%$ and the rest $(100 \%-61.2 \%=38.8 \%)$ are explained by other variables not included in the model.

Obtained the SEE value (Standard Error of Estimate) of 0.384. This means that the regression model error rate is $38.4 \%$. The smaller the SEE value, the regression model is better at predicting purchase decision.

\subsection{Normality Test}

Based on the P-Plot output, it can be seen that the points spread around the diagonal line and follow the direction of the diagonal line. Then it can be concluded that the regression model is normally distributed.

\subsection{Multicollinearity Test}

The results of the multicollinearity test show that all independent variables have tolerance values above 0.10 and VIF values below 10 . Then it can be concluded that there is no multicollinearity in the regression model used in this study.

\subsection{Heteroscedasticity Test}

The scatterplot output test results show that the points spread above and below 0 on the $\mathrm{Y}$ axis and do not form a clear pattern. So that it can be concluded that there is no heteroscedasticity in the regression model.

The Influence of Brand Equity to Purchasing Decisions on Wardah Products (studies conducted at Wardah Beauty House stores, Surabaya) 


\section{CONCLUSIONS AND SUGGESTIONS}

\subsection{Conclusions}

Based on the results and discussion in chapter IV, it can be concluded as follows:

1) Based on data processing using SPSS V.18.0. Obtained a $F_{\text {counts }}$ value of 39,992 . This value is greater than $\mathrm{F}_{\text {table }} 2,31$. Also obtained a significance value of $0,000<0,05$. This means that Ho is rejected and $\mathrm{Ha}$ is accepted, the brand awareness variable (X1), association (X2), perceived quality (X3) and brand loyalty (X4) have a simultaneous significant effect on purchasing decision variables (Y). This shows that each of the research variables is taken into consideration for prospective Wardah product customers.

2) Partially the four variables have their respective results, for the brand awareness variable the effect is not partially significant on consumer purchasing decision in Wardah products. This shows that the brand awareness is not too a consideration for prospective customers. Brand association variables have a partially significant effect on consumer purchasing decision in Wardah products. This shows that Wardah's brand association is in line with the expectations of prospective customers. Perceived quality variables have a partially significant effect on consumer purchasing decision in Wardah products. This indicates that Wardah's perceived quality is in line with the expectations of prospective customers. Brand loyalty variables have a partially significant effect on consumer purchasing decision in Wardah products. This shows that Wardah's brand association is in line with the expectations of prospective customers.

\subsection{Suggestion}

1) For Further Researchers

The suggestion for the next researcher is to identify other variables that influence consumers' purchasing decision, because the variables used in this study are only able to influence consumer buying intentions by $61.2 \%$.

2) For Companies

The tighter competition between cosmetic product manufacturers, the researchers suggest that Wardah pay attention to the four research variables used by researchers. Continue to improve the brand awareness even though the effect is not significant, but the brand awareness still has a stake in the basis of decision making for consumers. Wardah must also continue to improve its ability to association. In this study, brand association has the highest significance value. So brand association must be continuously improved so that it can influence consumers' purchasing decision very well. In this study perseived quality has a significant influence on consumer purchasing decision. Therefore Wardah must maintain and even increase its quality products. And also brand loyalty has a significant influence on consumer purchasing decision.

The Influence of Brand Equity to Purchasing Decisions on Wardah Products (studies conducted at Wardah Beauty House stores, Surabaya) 


\section{REFERENCES}

Aaker, D. (1991). Managing Brand Equity: Capitalizing on the Value of a Brand Name. New York: The Free Press.

Abdullah, T. dan F. T. (2013). Manajemen Pemasaran. cet. II. Jakarta: PT RajaGrafindo Persada.

Amstrong, dan K. (2003). Dasar-dasar Pemasaran, Jilid 1, Edisi Kesembilan. Jakarta: PT. Indeks Gramedia.

Darmadi Durianto, dkk. (2001). Strategi Menaklukkan Pasar Melalui Riset Ekuitas dan Perilaku Merek. Jakarta: PT. Gramedia Pustaka Utama.

Durianto, Darmadi, Sugiarto, L. J. B. (2004). Brand Equity Ten Strategi Memimpin Pasar. Jakarta: Gramedia Pustaka Utama.

Freddy Rangkuti. (2002). The Power Of Brand. Jakarta: Gramedia Pustaka Utama.

Kartono. (2007a). Analisis Elemen-Elemen Ekitas Merek. Jakarta: Gramedia Utama.

Kartono. (2007b). Analisis Elemen-elemen Ekuitas Merek Produk Minyak Pelumas Motor Merek Enduro $4 t$ (studi kasus pada mahasiswa universitas negeri semarang). Semarang: Karya ilmiah, Universitas Negeri.

Kotler dan Amstrong. (2008). Prinsip-Prinsip Pemasaran, Jilid 1 dan 2, Edisi 12. Jakarta: Erlangga.

Kotler, P. and K. L. K. (2016). Marketing Managemen, 15th Edition. Pearson Education,Inc.

Tjiptono, Fandy, Y. C. dan A. D. (2004). Marketing Scale. Yogyakarta: ANDI.

Tjiptono, F. (2005). Seri Manajemen Merek 01:Manajemen dan Strategi Merek. Yogyakarta: ANDI.

The Influence of Brand Equity to Purchasing Decisions on Wardah Products (studies conducted at Wardah Beauty House stores, Surabaya) 